\title{
The Performance Appraisal System: An Examination in The City School of Bahawalpur in Terms of Employee Perceptions
}

\author{
Muhammad Imran (Corresponding author) \\ Department of Management Sciences, The Islamia University of Bahawalpur \\ Email: imran_imranb2001@yahoo.com \\ Huzaifah Shafique and Nadeem Maqbool \\ Department of Management Sciences, The Islamia University of Bahawalpur
}

Doi: 10.5296/ijhrs.v4i1.5230 URL : http://dx.doi.org/10.5296/ijhrs.v4i1.5230

\begin{abstract}
Purpose: The purpose of this paper is to check the effectiveness of the performance appraisal system in private school.

Design/methodology/approach: Data were collected by survey questionnaire from a random sample of 44teaching staff in City school Bahawalpur branch.

Finding: The results are in first section, checking the status of performance appraisal system, overall 44 respondent which are employees all of them agreed with performance appraisal system status, in other words they perceived that performance system works effectively. In second section checking the impact of performance appraisal system on employees, I conclude that 28 employees affected by performance appraisal system.
\end{abstract}

Practical implications: The finding useful for management who are reviewing the operational effectiveness of performance management within own schools, as well as for organizations that are considering the introduction of performance management into their school system.

Originality/Value: This paper might be of particular value to national or private school management that wish to consider how to evaluate the effectiveness of various options before introducing a system of performance appraisal system.

Keywords: Performance appraisal system, Employees perception, Education sector, City school 


\section{Introduction}

The organization achievement rest on the quality and employees characteristics. The employees become an important factor in any institute because it is core of the institute. The school management cannot simply attain its goals and objectives without it. Though, the fact is that any employee in this regard needs to be something to make him or to look forward to be the motivation for the work is in the interest of the company. This is in fact indicates a more strategic approach to management (HRM) human resources management policies that sought to link the goals of the organization in the performance of the individual. The main objectives of the organization, and the goals and objectives become an integral part of the performance management process and send through the performance appraisal process. Performance appraisal system is more limited approach that involves managers make evaluation from top to bottom and rates the performance of their subordinates at an annual meeting to assess performance and ensure training need as well.

Present paper is an attempt to check the effectiveness of performance appraisal system of school education system. Researchers have attempted to explore various problematic issues or challenges which are being faced by school teachers regarding performance management. One of the leading private sector school known as The City School Bahawalpur Campus has been taken as a case study for the present research. In order to achieve possible data reliability qualitative and quantitative research methodology has been adopted. Distribute the Questionnaires among staff to check the employee performance, error in performance management system and check the employee perception related with effectiveness of performance management system.

The City School is a leading school education system in Pakistan. There are operated in 58cities of Pakistan and as well as internationally operated like England, Malaysia, UEA, Bangladesh, Philippine and Nepal. There is 7,000 teaching and non-teaching staff working in their all branches which operated in 58 cities.

The paper is organized into five sections. The next section is the literature review. The third section presents the methodology; fourth section is result and discussion. The final section presents the conclusions and recommendations.

\section{Objectives of the Study}

Mean of the study to assess the performance appraisal system and its effect on the performance of employees of the city school Bahawalpur branch. Specifically, the study attempted to check the following:

1. Check the effectiveness of performance appraisal system.

2. Check the impact of performance appraisal system on employee's performance.

3. Check the employee's perception regarding performance appraisal system working.

4. Identify the strengths and weaknesses of performance appraisal system in term of employee's perception. 


\section{Literature Review}

The author says that employees performance appraisal is a HRM tool. There are the following methods which used to measured or checked the employees performance and managed the employees performance as well .Methods are , appraisal interview, free essay, appraisal based on rating and ranking and the 360-degree feedback. These methods are simply measureable and not too time wasting, with the exemption of the 360-degree method. The 360 degree method is the smallest normally practical employee appraisal method (Kateřina, Andrea, \& Gabriela, 2003).

The author says that performance appraisal errors disturbing the work performances of the employees in these managements negatively will assist new strategies to improve their work performance. Therefore, work performances of employees rise, they will also contribute to rise organizational performance (Erbasi, Arat, \& Buyukipekci).

The author says that the performance appraisal system impacts on other HR functions like ensure the success of selection, training and motivation practices. The performance appraisal systems specifically; MBO, performance based pay and employee training has change the employee performance result as well. The factor; competence, assessment and development also change the employee performance (Messah).

The author says that an appraisal system has a clear sense of path, honest and meaningful feedback. There should be instant and honest strengthening and give a chance to employees to contribute in set the goals and standards for performance management. The purpose of appraisal system to allow for nonstop communication between management and teachers about job performance and as well as increased the organizational performance. Appraisal system must be assessed, analyzed and reviewed the result and present the need of training and employees competencies as well (Daoanis, 2012).

Author suggests the following key principles:

1. Performance management represents the people and its motivation.

2. Performance management enhanced the employee's performance.

3. Performance management should be a goal-driven process.

4. Performance management gives the rewards to the achievement of objectives.

5. Performance management is a management process. It is the relationship between a manager and employees (Hendry, Woodward, \& Bradley).

The performance management system contribute in organizational climate and culture, aimed at bringing about the alliance between individual values, group values and common values(Paauwe \& Boselie, 2005).

Justice is the main element in performance appraisal system experts may use our results to support their efforts to train managers in fair treatment during appraisals, as well as how to increase levels of apparent support, rather than just focusing on the reality of a fair appraisal 
procedure(Byrne, Pitts, Wilson, \& Steiner, 2012).

Employee's performance increased than they perceived and feel their work performance results are fair and accurate. Performance evaluator must be cooperative in performance appraisal give feedback to employee that will obviously increase the work performance and finally organizational performance will increase and the profitability and perception of fairness will be created in the employees of organization (Kaleem, Jabeen, \& Twana).

Meanness of all the efforts made by the organizations, the effectiveness of performance management system remains older area. The critical success factors of PMS are concerned, and then cannot be general (R.G.Ratnawat \& Jha, 2013).

The author says that performance appraisal system has a value of a back bone of every organization. The performance appraisal processes vital part of the HRM in the organization. Performance appraisal defines and measure and define the performance of the employees. It is a tool for assessing the performance of the employees and in turn the organization. Decision Support System which acts as a performance Appraisal System to monitor the performance of employees in any organization (Maheswari \& Kumari, 2013).

Performance management is enhancing performance quality and making motivation in employees and also performance evaluation improved the reviewing evaluation forms, changing and expressing more detailed and clear keys. Performance evaluation as a factor agent for effectiveness of any cultural, social and educational development program (Bahrami, abbasi, \& kajbaf, 2013).

The author says that satisfaction of the employees are highly associated with performance management system and several reaction measures like job satisfaction, performance appraisal fairness, developed the organizational goals (Krats \& Brown, 2012).

The author says that Performance management system mostly used as a managerial tool to contribution to motivating the organization performance, Execute the organizational strategy and achieving goals (Tung, Baird, \& Schoch, 2011).

The effects of certain personal background variables like job category, gender, type of departments and educational backgrounds on the apparent effectiveness. The job category and level of education, the employees meaning fully mixed in their observations about their performance appraisal system. These variables used to check the effectiveness of performance appraisal system (Sekhar, 2007).

The evaluator opinions of motivation effect the style in which employee performance is appraised, the applicability of evaluator concepts of subordinates is extended from the type of incentives programs evaluator plan and implement for employees, to the actual evaluation of whether these organizational deals are apparent as successful by evaluator (DeVoe \& Iyengar, 2004).

Author says that PM gives you desired requirements for an effective system and staff support to system. On the other side, a problem does exist from the state agencies. In most schools, performance appraisal system is primarily development and do not meet administration 
requirements. The principals will developed system that priorities their own requirements and those they apparent to be important to their staff, rather than satisfy the requirements of the state (Timperley, 1998).

Constant review of system and positive feedback along the way will enhance the employee performance. The school administration takes initiative in developing a strong performance appraisal process, defining the employee as well as top management effectiveness will naturally be confirmed (Anderson \& Kleiner, 2003).

The author suggests that schools desire to evaluate teaching utilizing peer observation would be counseled, Performance management maximized the advantages and minimized the disadvantages, Performance management reshaping of teaching norms, a change in faculty members, beliefs and values, and a culture that is prepared to accept positive blame and one that sees such blame as an opportunity for improvement rather than a threat (Blackmore, 2005).

The author says that performance appraisal identify the following:

Self-evaluation, Contributes by satisfied to the principle of self-evaluation, Inspires discipline at work by lessening absence ,Develop employees performance ,Contributes to defining training need, and encourages taking training courses as well (Al-Hamdan \& Al-Yacoub, 2005).

The author says that the performance appraisal affective and clearly explained to employees, there is a high chance that it could be implemented with a high degree of importance and tolerability. Many evaluation tools are evaluate the teaching performance, self-evaluation, peer evaluation and provide complete useful information as well (Ngware \& Ndirangu, 2005).

Performance evaluation is around efficiency, productivity and utilization. It is reductionist concept based on the performance management administration (Radnor \& Barnes, 2007).

The author says that performance appraisal system can be successfully used for guiding and motivating the academic staff (Turk, 2008).

Author says that school supervision and school evaluation having a positive and negative impact (Lee, Ding, \& Song, 2008).

Performance management is developing in schools than P.M monitor exam results, progression and completion rates. PM is systematic way in which find the difficulties in results and understanding with reasons. Performance management measures the overall performance of the exam system and improved the examination system and take improvement action as well. Sometime agreement with external evaluation of school has promoted and developed the self-evaluation system (Sarrico, Rosa, \& Manatos, 2012).

The author says that chooses the right employee for right compensation; avoid the non-performer employee for reward. Made the clear policies for compensation and work performance achievement (Shah \& Nair, 2012). 


\section{Macrothink

Author says that made the model, in which performance management is important for employees attitude and behavior development, Employees motivation, Organizational aims, relationship between management and staff as well(Ahmed, Sultana, Paul, \& Azeem, 2013).

The author says that performance management provide the information in schools about: the purpose of performance appraisal in school is that provide education training for performance management, formulate the performance management objectives, measuring the employees performance, professional development and managed the reward system on the basis of performance results(Brown, 2005).

\section{Research Methodology}

\subsection{Research design}

This research adopted a descriptive design research. For this purpose city school Bahawalpur branch were visited. The main interest is to explore the performance appraisal effectiveness and employees perception according to performance appraisal. Descriptive research design method provided quantitative data from cross section of the chosen population. That researched having a three parts: (1) Focused on performance appraisal effectiveness (2) Focused on performance appraisal impact on employees performance. (3) Focused on employees perception, checked the how performance management system worked.

\subsection{Target population}

The target population of this study was the teaching staff working in branch of the city school of Bahawalpur.

\subsection{Data collection}

The questionnaire to use for collects the primary data collection instrument. The questions are designed to collect qualitative and quantitative data.

\subsection{Data analysis}

The data gathered with help of questionnaire technique and using the Statistical Package (SPSS) to analyze and drives the result. The percentile technique was used for the assessment of the respondents in the status and the impact of the performance appraisal system of the school staff performance.

\subsection{Ethical Considerations}

In this study maintained the confidentiality of respondent. Asked the no personnel question from participant and if you having an issue with participant so clear the issue. 


\title{
5. Results and Discussion
}

\subsection{Results of Performance Appraisal System Effectiveness}

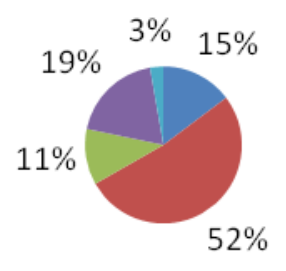

\author{
- Strongly Agree \\ Agree \\ Indifferent \\ 口isagree \\ - Strongly Disagree
}

Table 4.1 shows that $67 \%$ employees agreed, $11 \%$ employees indifferent, $22 \%$ employees disagree with (Performance Appraisal System status, in other words they perceived that performance system works effectively).

\subsection{Impacts of Performance Appraisal System on Employees Performance}

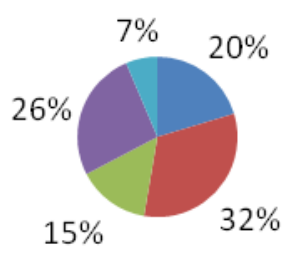

\author{
- Strongly Agree \\ Agree \\ Indifferent \\ Disagree \\ - Strongly Disagree
}

Table 4.2 shows that $52 \%$ employees agreed, $15 \%$ employees indifferent, $33 \%$ employees disagree with (impact of performance appraisal system on employees Performance, in other words 23 employees affected by performance appraisal system).

\section{Conclusion and Recommendations:}

From the above analysis it is concluded that in first section of checking the status of performance appraisal system, overall 44 respondents which are employees all of them agreed with performance appraisal system status, in other words they perceived that performance system works effectively. In second section checking the impact of performance 


\section{IIMacrothink}

appraisal system on employees, I conclude that 28 employees affected by performance appraisal system.

The following recommendations are given below

- Enhanced the teaching skills.

- Make sure the leadership skill of employees.

- Provide the career management opportunities.

- Provide proper training to enhance the work skills.

- Motivation enhancement activities should be provided to every employees.

- Evaluation Feedback must be provided to every employees.

- Employees should be involved in appraisal tool formulation.

- The evaluation of employees should be honest and fair.

- Control the gender discrimination and diversity.

- Appraisal system must have clear sense of direction.

\section{References}

- Ahmed, I., Sultana, I., Paul, S. K., \& Azeem, A. (2013). Employee performance evaluation: a fuzzy approach. International Journal of Productivity and Performance Management, 718-734.

- Al-Hamdan, J. M., \& Al-Yacoub, A. M. (2005). Evaluation of section heads' performance at Kuwait secondary schools. International Journal of Educational Management, 233-245.

- Anderson, B., \& Kleiner, B. H. (2003). How to Evaluate the Performance of Chief Executive Officers Effectively. Management Research News.

- Bahrami, A., abbasi, Z., \& kajbaf, m. b. (2013). Study manager' evaluation form according to teachers and managers. International Journal of Scientific \& Engineering Research, Volume 4, Issue 8,, 07.

- Blackmore, J. A. (2005). A critical evaluation of peer review via teaching observation within higher education. International Journal of Educational , 218-232.

- Brown, A. (2005). Implementing performance management in England's primary schools. International Journal of Productivity and Performance Management, 468-481.

- Byrne, Z. S., Pitts, V. E., Wilson, C. M., \& Steiner, Z. J. (2012). Trusting the fair supervisor: the role of supervisory support in performance appraisals. Human Resource Management Journal, 19. 
- Daoanis, L. E. (2012). PERFORMANCE APPRAISAL SYSTEM: It's Implication To Employee Performance. International Journal of Economics and Management Sciences Vol. 2, No. 3, 2012, pp. 55-62, 08.

- DeVoe, S. E., \& Iyengar, S. S. (2004). Organizational Behavior and Human Decision Processes, 47-61.

- Erbasi, A., Arat, T., \& Buyukipekci, S. (n.d.). THE EFFECT OF PERFORMANCE APPRAISAL ERRORS ON EMPLOYEE PERFORMANCES: AN EXAMINATION IN INDUSTRIAL COOLING MANAGEMENTS IN TURKEY IN TERMS OF EMPLOYEE PERCEPTIONS. European Scientific Journal, 23.

- Hendry, C., Woodward, S., \& Bradley, P. (n.d.). Performance and rewards: cleaning out the stables. HUMAN RESOURCE MANAGEMENT JOURNAL, 17.

- Kaleem, M. M., Jabeen, B., \& Twana, M. J. (n.d.). Organizational Justice in Performance Appraisal System: Impact on Employees Satisfaction and Work Performance. International Journal of Management\& Organizational Studies, 10.

- Kateřina, V., Andrea, Š., \& Gabriela, K. (2003). Identification of Employee Performance Appraisal Methods in Agricultural Organizations. Journal of Competitiveness, 17.

- Krats, P., \& Brown, T. C. (2012). Unionised employee's reactions to the introduction of a goal-based performance appraisal system. Human Resource Management Journal, 17.

- Lee, J. C.-k., Ding, D., \& Song, H. (2008). School supervision and evaluation in China: the Shanghai perspective. Quality Assurance in Education, 148-163.

- Maheswari, A., \& Kumari, P. (2013). A Performance Appraisal Model using Fuzzy Multi Criteria Group Decision Making. International Journal of Scientific \& Engineering Research, 08.

- Messah, O. B. (n.d.). The Effect of Performance Appraisal Systems on Employees in Kenya Tea Development Agency: A Survey of Selected Tea Factories in Meru County-Kenya. Research Journal of Finance and Accounting, 20.

- Ngware, M. W., \& Ndirangu, M. (2005). An improvement in instructional quality: can evaluation of teaching effectiveness make a difference? Quality Assurance in Education, 183-201.

- Paauwe, J., \& Boselie, P. (2005). HRM and performance: what next? Human Resource Management Journal, 16.

- R.G.Ratnawat, \& Jha, D. P. (2013). A Commentary on Effectiveness of Performance Management. International Journal of Scientific \& Engineering Research, 12.

- Radnor, Z. J., \& Barnes, D. (2007). Historical analysis of performance measurement and management in operations management. International Journal of Productivity and Performance Management, 384-396. 
- Sarrico, C. S., Rosa, M. J., \& Manatos, M. J. (2012). School performance management practices and school achievement. International Journal of Productivity and Performance Management, 272-289.

- Sekhar, S. F. (2007). ASSESSMENT OF EFFECTIVENESS OF PERFORMANCE APPRAISAL SYSTEM: SCALE DEVELOPMENT AND ITS USAGE. ISSN.

- Shah, M., \& Nair, C. S. (2012). The changing nature of teaching and unit evaluations in Australian universities. Quality Assurance in Education, 274-288.

- Timperley, H. S. (1998). Performance appraisal: principals' perspectives and some implications. Journal of Educational Administration, 44-58.

- Tung, A., Baird, K., \& Schoch, H. P. (2011). Factors influencing the effectiveness of performance measurement systems. International Journal of Operations \& Production Management, 1287-1310.

- Turk, K. (2008). Performance appraisal and the compensation of academic staff in the University of Tartu. Baltic Journal of Management, 40-54. 